\begin{tabular}{l} 
Year:5, Volume:5, Number:9/2021 \\
\hline $\begin{array}{l}\text { The } \\
\text { Sournal of } \\
\text { Science }\end{array}$
\end{tabular}

DOI: $10.30520 /$ jsosci. 870897

\title{
CONCEPTUALIZING STRATEGIC RISK-TAKING BY SMALL STATES UNDER GAME THEORY (A CONSTRUCTIVIST ANALYSIS)
}

\author{
Shakaib RAFIQUE ${ }^{1}$
}

\begin{abstract}
This paper undertakes a constructivist analysis of Game Theory approach and presents the co conceptualization of different players in a system i.e. small states, hegemonic and counter-hegemonic states on the basis of role conceptualization, perceptions, ideals and beliefs regarding "self" and "others". The paper then presents the dilemma faced by a small state in a system while dealing with the hegemon and counter-hegemon and introduces the concept of strategic risk-taking to encapsulate that any action (or inaction) by the small state in a system, even if it be seemingly docile in character aimed at ensuring state sovereignty, is contingent upon the perceptions, beliefs and ideals of the hegemon and counter-hegemon. The paper further argues that any action or inaction by the small state even for securing its sovereignty is deemed a risk-taking action or inaction by the greater power, mostly hegemon. The paper while presenting the case studies from South Asia explores as to how the strategic risk-taking by small states, as perceived by the hegemon or counter-hegemon leads to a lose-lose situation through creation of security dilemmatic situation as a final outcome of the gaming approaches.
\end{abstract}

Keywords: Game Theory; Small States, Constructivism; South Asia; Strategic Risk-taking; Neutrality; Bandwagoning: Strategic Hedging

\footnotetext{
${ }^{1} \mathrm{PhD}$ student, National University of Political Studies and Public Administration, Bucharest, Romania (irtiqa1000@gmail.com)
} 


\section{INTRODUCTION}

Before we embark upon the conceptualization of "strategic risk-taking", it would be useful to recapitulate the basic tenets of constructivist theoretical framework, followed by assessment of Game Theory through the prism of constructivism. As per Guzzini, 'Constructivism' is basically a "meta-theoretical commitment" whose main tenets include inter alia that social reality is constructed and that reality as well as knowledge are mutually constitutive (Jung, 2019). The focus of constructivist analysis is on such non-material factors as ideas, norms, knowledge and culture while it lays particular emphasis on the inter-subjective ideas as well as understandings regarding social life (Jung, 2019) (Finnemore \& Sikkink, 2001). The basic assumptions of constructivist theoretical framework include shaping of human interaction by ideational rather than material factors and beliefs constructing the interests as well as identities of actors or players (Finnemore \& Sikkink, 2001) (Jung, 2019).

In recent years, the use of Game Theory approach in International relations has increased in a significant manner (Kapor, 2016). Game Theory is essentially a segment of decision theory and studies cooperation and conflict. Under this theory, a "game" describes an "interactive strategic situation" wherein players may range from individuals to states (Kapor, 2016). Roger B. Myerson defines Game theory as "the study of mathematical models of conflict and cooperation between intelligent rational decision-makers" (Myerson, 1991). He further elaborates the concept of "game" by suggesting that it alludes to a certain "social situation" that involves two or more players. Game theory is also defined as a "systematic study of strategic interactions among rational individuals (Kockesen \& Ok, 2007). An important concept defined under the Game Theory is called "strategy" which is essentially defined as the possible action of a certain player (Kapor, 2016). In a 'game', players choose from different strategies. In its extensive form, a "strategy" constitutes an entire choice plan (Kapor, 2016).

There are two basic assumptions concerning the players in a 'Game Theory', the first being that they are rational and second that they are intelligent (Myerson, 1991). As for the player or "decision-maker" it is considered to be rational if its decisions remain in pursuit of its identified objectives on a consistent basis. Furthermore, it is the objective of each player to maximize "expected value of own payoff", measured in terms of some "utility" (Myerson, 1991) or minimize losses under the circumstances governed by uncertainty and incomplete information (Tema, 2014). As we would undertake a constructivist analysis of the Game Theory approach in the following sections, it may be useful to underscore at this stage that the term rationality when seen in light of the definition offered by Myerson clearly indicates that it is in consistent pursuit of some objective, which is linked up with ideals and beliefs of the particular player under scrutiny. Accordingly, the element of utility and maximization of payoff may not necessarily be seen in monetary terms (Myerson, 1991). Utility can therefore be linked up with the achievement of the ideals and goals identified on the basis of the beliefs and perceptions of the concerned state.

One can discern from the above conceptualization of 'game theory' that its subject matter pertains to the interactions among a certain group of players and accordingly their actions affecting the overall outcome (Kockesen \& Ok, 2007). This implies that for a certain situation or interaction to be considered under the 'game theory', it has to be strategic in character i.e. the players should be cognizant that their actions would affect others (Kockesen \& Ok, 2007). 
Based on the number of players as well as the structure of payoffs, the "games" within a "game theory' could be either cooperative in nature or conflictual in character (Kapor, 2016). For instance, a cooperative game identifies the payoffs that each potential coalition can gain through cooperation among its members (Kapor, 2016). On the other end, under a non-cooperative (or conflictual game, italics mine), essentially the process of choices made by players in their own "best interest" is modeled and in this context the timing and ordering of these choices are crucial for the purposes of determining the games' outcomes (Kapor, 2016).

Another important concept to identify under the game theory which would be helpful while undertaking a constructivist analysis of this approach is the notion of "priors". 'Priors' constitute an important rule of the game and are basically the beliefs that players hold about the other players and update in the course of the game as they observe the actions taken by other players under an assumption that these players are pursuing an "equilibrium behavior" (Rasmusen, 2004).

\section{IDENTIFYING 'PLAYERS' FOR GAME THEORY APPROACH}

Having examined the main elements and contours of the game theory, we now introduce the concept of players with asymmetric power i.e. hegemonic states; counter-hegemonic states and the small states.

Inequality in power distribution among sovereign states constitutes a fundamental characteristic of international politics (Efremova, 2019). It is normally assumed that the interactions among great powers define global and regional systems while the small states generally acquiesce to the rules of game established by the greater powers (Efremova, 2019). However, scholars such as Womack argue that although by definition, the asymmetric relationships are unequal, yet in such a relationship, small states interact more than the greater powers and these greater powers do not dictate the relationship unilaterally (Womack, 2016).

A central element in all the conceptualizations of smallness includes the scarcity of capabilities as well as resources that establish influence and power (Steinsson \& Thorhallsson, 2017). There are essentially two strands of definitions used to conceptualize a small state or a great power. These include absolute and relative definitions (Efremova, 2019). Absolute definitions employ quantitative criteria to distinguish between a small and a great state. These include inter alia territorial size, national income or population to name a few. As an example for instance, the Commonwealth employs population criterion to define a small state as any country having less than 1.5 million people (Efremova, 2019). However, since international politics is defined by interactions between states, what is more important in terms of defining a small and a larger or greater power is their roles (Efremova, 2019). Accordingly, the relative definitions appear more appropriate for distinguishing between a small and greater power. Under these definitions, power is taken as a variable when states are compared to each other (Efremova, 2019).

Under the relative definitions, there is a category that underscores the qualitative power differential between states. Accordingly, as per Vandenbosch, a "small state" is the one that is not able to compete in war with the great powers on equal terms (Vandenbosch, 1964). The small states play an insignificant role in global politics that makes them "stakes" instead of "players" (Heng \& Aljunied, 2015). It is also argued that "small states" are unable to guard themselves 
against the aggressors and therefore have to rely on other states or the international organizations for retaining their sovereignty (Goodby, 2014).

Another way of conceptualizing a certain state as small or great is through the identities and roles that it assigns to itself in the system and the manner in which it perceives its "self" in contradistinction to the "other" states. It is essentially, this definitional framework that we would be employing throughout this paper as well.

As for the state identities, constructivist theoretical framework identifies these as being socially constructed and having influence on the state actions and interests (Ilgit \& Ozkececi-Taner, 2012). As per Hopf, 'state identity' is a product of interaction that a state has with its society (Hopf, 2002). Accordingly, for Hopf, the domestic identity discourse of a state institutes the "social cognitive structure" that assists that state in understanding itself as well as "others" in global politics while also identifying the opportunities and threats as well as allies and enemies (Hopf, 2002) (Ilgit \& Ozkececi-Taner, 2012).

As per the constructivists, the state identities contour perceptions regarding their interests and assumptions as to what behavior is appropriate in a given situation (Larson, 2012). Wendt employs the notions of symbolic interactionism and role for explaining the state identities (Wendt, 1999). Accordingly, from the standpoint of symbolic interactionism, "self" is defined through social categories as well as the corresponding roles (Wendt, 1999) (Larson, 2012). Roles are social because they presume shared expectations about behavior appropriate to the role (Wendt, 1999) (Larson, 2012). As per Wendt, "roles" are social in character as they presuppose a counter role (Wendt, 1999) (Larson, 2012).

Based on the above conceptualization, one can discern that for a state to be considered small or otherwise, it is important to look at the manner in which it socially constructs its own identity and role. Furthermore, it is important to note that a State also sees itself in relative terms while identifying its role and status in a system. At this stage, it would be useful to bring in the conceptual distinction between the strong and small states, as elaborated by Buzan who suggests that "strong state defines itself from within and fills the gap between its neighbours". Buzan highlights that a small state is actually "weak" in comparison to surrounding nations. He suggests that the weakness of small states "is relative to the capabilities commanded by other states". In respect of small states and great powers, Bjøl states that the national interests of small states are narrow, while the great powers have a broader international agenda owing to the consideration of prestige. Accordingly, the leadership of "great powers" conceptualizes their state's national security as the ability to project power while the leadership of small states perceives the national security as the "capability" to deter foreign interference in their state in an effective manner (Efremova, 2019) (Bjøl, 1971).

From the above assessment of the notion of small states and great powers, one can discern that as per the constructivist theoretical framework, what is important for a state to be considered small or great is basically the role that it believes it has within the system and the manner in which it perceives the role of "other" states. Taking clue from this approach, for a small state, capabilities are also contingent upon the manner in which the leadership of that country visualizes its role based on the perceptions, ideals and beliefs concerning itself in contradistinction to others. It is because of these cognitional elements that a state may not necessarily have lesser material resources or geographical space or population to be considered a small state. This aspect clarifies 
a number of anomalies associated with the attempts to define a small or great state on the basis of material factors only. For instance, Namibia despite being the $34^{\text {th }}$ largest country in the world in geographical terms is considered to be a small state (Mushelenga, 2015) as it does not envision any wider global role for itself. The relevant principles enshrined in the Namibian Constitution essentially only envision that the country does not face any consequences associated with the global conflicts (Mushelenga, 2014). In a similar manner, if seen from the standpoint of constructivist theoretical framework, the corollary of Qatar can also be resolved. While normally considered to be a small state through certain quantitative criteria, Qatar has been pursuing, in recent years, a much active international agenda and appears to have the quest for attaining an internationally significant position (Mohammadzadeh, 2017). This leads us to conclude that it is essentially based on the specific role assumed by a state in respect of "itself" vis-à-vis "others" that the status of a state being small or otherwise can be defined.

\section{SMALL STATE'S DILEMMA IN A “GAME"}

In a "Game", the basic underlying motivation for a small state remains the retention of its sovereignty. The "Maximin" or the maximization of the least possible benefit/utility for a small state would therefore be the retention of its sovereign status at any cost. As for the possible perceptions, a small state could either consider the hegemon to be guarantor of its sovereignty (and consequently, a counter-hegemon as a threat to its sovereignty) or may consider that the hegemon is indeed a threat to its sovereignty (and consequently a counter-hegemon as a possible guarantor of its sovereignty). In case a small state considers a hegemon to be a threat, the small state may either consider it expedient to become more dependent on the hegemon with the ideal of retaining as much internal autonomy as possible (in case there does not exist any counterhegemon) or search for a counter-hegemon to throttle any attempts by the hegemon to overpower that small state.

As for the hegemonic state, recognition of its status by the small states is an important consideration. For the hegemon, therefore, the 'priori' is that the small states remain dependent on it. Any departure from this 'status quo' would be considered a hostile act by the hegemon.

For a counter-hegemon, titling the regional balance in its favor and assuming regional leadership remains a priority. For doing so, a counter-hegemon would normally attempt to incentivize the small state to enter it into its camp.

We would now briefly discuss the nature of dilemma that a small state confronts in a game when dealing with a hegemon and a counter-hegemon with the objective of retaining its sovereignty. We would first assess the strategy of 'neutrality' posture by small state in respect of a hegemon and a counter-hegemon. A small state would be confronted with a complicated situation if it would try to act neutral for the purposes of securing its sovereignty. For instance, in case it attempts to remain neutral between a hegemon and a counter-hegemon, this may not be acceptable for hegemon, as it may take this as a possible future challenge for its hegemony or a step away from its sphere of influence by the small state. It is because; neutrality does not necessarily imply acceptance of hegemon's predominance but also the likely recognition of existence of two hegemons at the same time. A neutral posture may also be seen quite differently by a counter-hegemon. It may take this position of the small state as an opportunity and accordingly try to incentivize the small state. However, such an act may invite awe from the 
hegemon for the small state as well as the counter-hegemon leading to system instability through economic sanctions or arms race etc.

Another possible gaming strategy that the small state can adopt is called 'bandwagoning wherein, the small state may either enter into alliance with the hegemon or the counter-hegemon for protection of sovereignty. However, the negative implications of this policy are obvious in the long run as the greater player against whom the small state bandwagons would consider it an unfriendly act and may strategize accordingly to devein the small state from that alliance formed against it (i.e. hegemon or the counter-hegemon). In another sense, the 'bandwagoning' could also likely result in compromise on the small state's sovereignty which is the least that it could afford.

The strategy that is oft presented as a possibility for a small state, especially if it exists as a buffer between a hegemon and a counter-hegemon, is that of 'strategic hedging'. This strategy implies that the small state mixes its tactics in a manner so as to reduce the risks and threats associated with making a choice unacceptable to either the hegemon or a counter-hegemon. 'Strategic hedging' essentially explains the behavior of states that seek to improve their competitiveness for the purposes of reducing the gap with the leader in the system while avoiding open provocation through evading internal and external balancing (Salman \& Geeraerts, 2015) (Tessman \& Wolfe, 2011). Accordingly, this strategy is considered to be less confrontational than traditional balancing, less cooperative than bandwagoning and more active than buck passing (Tessman B. , 2012) (Efremova, 2019). However, if one takes a closer look at the strategic hedging, through constructivist theoretical framework, it is not without its own associated risks either. The main problem associated with this strategy is that it ignores the possibility of likely reaction from the hegemon and counter-hegemon based on their perceptions concerning the policy approach adopted by the small state. For instance, if a small state attempts to hedge by appearing to be less confrontational than traditional balancing, without appearing to be taking sides, the hegemon and counter-hegemon may take this ambiguity to be counter-productive for their ambitions and thus this perception may provoke either of these greater players, especially the hegemon, to seek more clarity in terms of statement of preferences by the small state. On the other end, if a small state adopts the strategy of being less cooperative than bandwagoning, the hegemon or the counterhegemon may again take it as insufficient and demand more from the small state through measures that may even be punitive in character.

\section{STRATEGIC RISK-TAKING}

At this stage, we would now introduce the concept of "strategic risk-taking" through the constructivist theoretical framework and attempt to elaborate that what actually encompasses the dilemma of a small state in a game is that rather than acting neutral, bandwagon or hedge, a small state is actually perceived to be taking risks all the time. It is this strategic risk-taking that leads to lose-lose situation for all players in the system. This also forms the hypothesis which we would be testing through the case studies of South Asia in the latter part of the paper.

Concept of risk-taking is known to us through the 'Prospect Theory'. "Risk" is considered to be of huge significance in terms of making a choice and is envisioned in terms of "relative threat to values" (McDermott, 1998). Accordingly, this concept implies either the fear of losing something of value or failing to achieve some objective (McDermott, 1998). There are normally two elements associated with the risk attitudes i.e. risk-aversion and risk-seeking behaviors. In terms 
of 'Prospect Theory' of International Relations that tends to elaborate the notion of risk attitudes, individuals (or States, italics mine) tend to make decisions on the basis of certain reference points rather than final outcomes (Vis, 2018). This reference point is also called "status quo" (McDermott, 1998). As per the Prospect Theory, the states tend to have a "status quo bias" which implies that the disadvantages associated with departing from the status quo are valued more than the parallel advantages related to this departure (Levy, 1992). Accordingly, as individuals (or States italics mine) make decisions that involve certain losses of moderate nature, they tend to seek risks, while on the other end, in case of gains of the same nature, they tend to avert risks (Vis, 2018) (McDermott, 1998). Taken in this sense, the Prospect Theory is assessed as a psychological alternative to the rational choice (O’Neill, 2001).

In contrast to the above conceptualization, the notion of "strategic risk-taking" being presented in this paper is based on the basic assumption that risk-taking is contingent upon the perceptions of the states against whom, such action (or inaction) is taken by the small state. Furthermore, 'rationality' in terms of strategic risk-taking depends on the perceptions, beliefs and ideals of the states which serve as the parameter to gauge 'utility' of a certain action (or inaction). Another important constitutive element of "strategic risk-taking" is that it is not necessary for a state to be a risk-taker in order to avert a marginal loss or oriented towards risk-aversion in case of a marginal gain. A state is indeed always taking risks from the standpoint of 'others' i.e. hegemon and the counter-hegemon.

We would now examine the theoretical manifestation of the concept of strategic risk-taking.

For securing its sovereignty or with a peculiar role conceptualization of being a necessary weight in the system for deciding regional leadership of a hegemon or a counter-hegemon, when the small state adopts any course of action, be it balancing relations with the hegemon and the counter-hegemon, bandwagoning a hegemon or counter-hegemon or acting neutral between the greater powers in the system, it is always perceived as a risk-taking endeavor by either of the greater powers and mostly by the hegemon. In such a situation, the associated risk factor in terms of possible reaction from greater powers could be of different forms. For instance, a hegemon could perceive that the small state is actually out of its basket and may embark upon punitive measures against the small state. As the small state would still be on the course to reducing its gap with the greater power (i.e. hegemon in this case), it may have to ultimately fall into alliance with the counter-hegemon even if it wanted to reap benefits from both hegemon and the counterhegemon. For a counter-hegemon, while such a situation may apparently add a score against the hegemon by making a new ally in the region, it could also face a security dilemmatic situation initiated by the hegemon in the region through measures including inter alia arms race, economic sanctions etc. This security dilemmatic situation could therefore lead both hegemon and counterhegemon to start climbing the escalation ladder much faster than anticipated, as both sides would attempt to steal the power show. Meanwhile, the small state, in its bid to enhance sovereignty by increasing its profile as a player rather than a "stake", may even run the risk of losing its sovereignty altogether, especially if the hegemon or counter-hegemon, with whom the small state aligns itself, considers it expedient to remove that grey area.

As for the so-called strategic hedging, as mentioned earlier, the perceptions of hegemon would most likely be negative as it would see even a seemingly docile move by the small state to secure its sovereignty or reduce its dependence, as a hostile act. 
In sum, the small state always remains in a dilemma when it comes to its gaming approaches visà-vis a hegemon and counter-hegemon, resulting in perpetual threat to its sovereignty. As we would notice from the case studies of South Asian region, this strategic risk-taking could even lead to complete loss of sovereignty for small states in certain cases.

\section{CASE STUDY OF SOUTH ASIA}

South Asia is comprised of eight states, if one goes by the membership of the South Asian Association for Regional Cooperation (SAARC). These include Afghanistan, Bangladesh, Bhutan, India, Maldives, Nepal, Pakistan and Sri Lanka.

Since its creation in 1947, India's foreign policy towards South Asia has remained premised on considering this region as its "sphere of influence". Accordingly, India considers the entire region of South Asia its own civilizational space and has a perception regarding itself of being a natural hegemon for the entire region (Wojczewski, 2016).

China perceives itself to be a counter-hegemon against the hegemonic designs of imperialist powers exercised through India in South Asia (Tahir-Kheli, 1978). In a similar manner, most of the small states of South Asia, owing to their resentment with India's hegemonic designs for the region regard China, a "stabilizing factor" (Saleem, 2013).

\subsection{NEPAL}

Following India's creation in 1947, that country took up the mantle of British imperialism in the region and accordingly, Nepal signed the 'Peace and Friendship Treaty' with India in 1950 (Suhrwardy, 1996). With this treaty, Nepal was practically forbidden from diversifying its relations beyond India and any attempts by the former to do so were discouraged by India in order to keep the so-called "inner buffers" (including Nepal, Sikkim and Bhutan) well within its influence (Feer, 1953) (Adhikari, 2018).

It may be highlighted that despite the above Treaty, Nepal's King Mahendra is accredited with trying to diversify his country's foreign relations beyond India. By the time of King Mahendra, it was considered that the 1950 Indo-Nepal Treaty as well as a subsequent Trade Treaty between India and Nepal had actually compromised the latter's independence (Adhikari, 2018). Accordingly, Nepal made the move of re-establishing diplomatic relations with China in 1955 (Adhikari, 2018). In 1960, Nepal also concluded a Peace and Friendship Treaty with China. During this timeframe, Nepal also established diplomatic relations with some other extra-regional powers such as the US and Germany (Adhikari, 2018). During this period, Nepal also declared its neutrality and non-alignment. However, this act was resented by India (Adhikari, 2018). This explains that for a small state, even the act of so-called neutrality may be taken as a loss by the 'Hegemon' and an attempt of strategic risk-taking by the small state. Owing to its peculiar perception regarding Nepal of acting belligerent, India imposed a trade blockade on Nepal in 1989 (Adhikari, 2018) that ultimately led to end of absolute monarchy in the country in 1990.

Following the restoration of multiparty parliamentary system of democracy in Nepal in 1990, Nepal's interim Prime Minister Krishna Prasad Bhattarai reverted to closer relations with India (Upadhya, 2012) (Adhikari, 2018). This, however, initiated great power rivalry for gaining influence in Nepal. The period 1996-2008 was marked by increasing extra-regional influence as well as civil war in Nepal (Adhikari, 2018). In 2008, as democracy was restored in the country, 


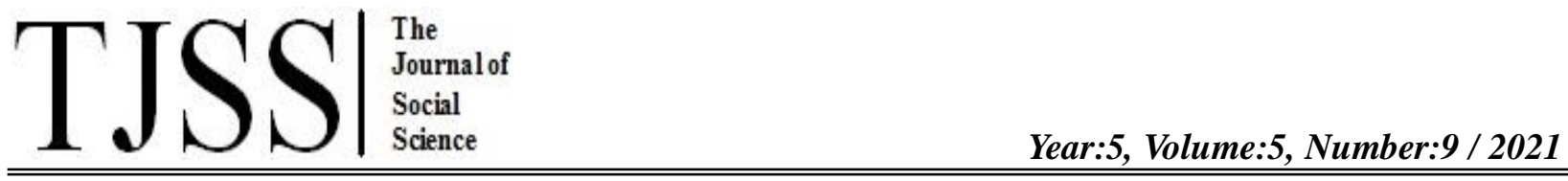

Nepal started following the policy of "equiproximity" with its bigger neighbors i.e. India and China (Adhikari, 2018). This concept was intended to assert Nepalese independence and sovereignty by opening the option of reviewing all the previous treaties unfavorable to Nepal's national interests, with a focus being on ending special relations with India. This was compounded by the proposal by Nepal to have a trilateral cooperation with China and India in the domains of tourism development as well as infrastructure (Adhikari, 2018). These developments clearly indicate that through the above developments, Nepal was now posing itself to be a state aiming at dealing with China and India from the standpoint of parity. This ambitious approach also hints that Nepal by this time had realized that it was rather inevitable for the greater regional powers and could therefore play its cards more confidently. However, this approach was again perceived by India as a negative development and a risk-taking attempt by Nepal to steer away from Indian sphere of influence. Accordingly, since 2008, India started supporting Madhesi separatists and even threatened Nepal that any law enforcement measures against the Madhesi militants could result in a breakup of Nepal (Kantha, 2010). India also subsequently used the Madhesis in Nepal to block the Indo-Nepal border area and stopped goods supplies to Nepal (BASU, 2020). Accordingly, Madheshi card is quite often used by India to check Nepal from drifting away from its sphere of influence.

In recent years, Nepal has been pursuing an ambitious foreign policy in respect of its neighbouring powers i.e. India and China. Nepal now sees its more prominent role in respect of its neighbors and wants to become a 'vibrant economic bridge' between India and China (Adhikari, 2018). This clearly signifies that Nepal wants to graduate from the small state status and perceives its destined role to be much larger that of a small state. Furthermore, Nepal has embarked upon more aggressive strategic risk-taking when it comes to its relations with great regional powers. In respect of India, Nepalese Prime Minister Oli's foreign policy based on strategic risk-taking is reflected through introduction of new map of Nepal following inauguration of a link road through Kalapani to Mansharovar by India (India Today Web Desk, 2020). Furthermore, Nepal has been making more proactive overtures towards China in recent years especially manifested through signing of transit and trade agreements with China in 2016 (Haidar \& Bhattacherjee, 2016) as well as high level visit by Chinese President Xi to Nepal in 2019 (Associated Press, 2019). As mentioned earlier in the theoretical segment, however, this approach has had its own unique impact on Nepal. India, for instance, has not been receptive to this approach by Nepal and has received the above signaling by Nepal in a negative manner. Resultantly, it has been alleged that India has already started creating rifts within the Nepalese Government (HIMALAYAN NEWS SERVICE, 2020). In recent months, the rivalry between India and China for greater influence in Nepal has also increased with the recent visit of Indian Army Chief (Press Trust of India, 2020) (Press Trust of India, 2020) and Foreign Secretary followed by Chinese Defense Minister (Press Trust of India, 2020). The recent manifestation of the above power tussle is the dissolution of Nepalese Parliament on the advice of Prime Minister Oli, who sees increased Indian interference in the country's politics (FP Staff, 2020).

The above situation manifests the stage under the strategic risk-taking wherein both the hegemon (in this case India) and counter-hegemon (i.e. China) are now attempting to enhance their influence in Nepal. This could also be seen in parallel with the ongoing border tensions between India and China that seems to have created a security dilemmatic situation having its implications for Nepal, whose Government led by Prime Minister Oli in its own turn had directed the 
Nepalese forces to "closely monitor" the activities of the Indian Army in Lipulekh area (IANS, 2020). Overall, this situation may lead to Nepal facing challenges pertaining to securing its sovereignty in the longer run.

\subsection{SIKKIM}

In 1947, when India was created out of the British Indian Empire, it concluded a standstill agreement with Sikkim through which the latter managed to retain its internal autonomy (Bhutia, 2017). However, as India's leadership of the time had already envisioned a great power status for their newly created country and considered the Himalayan states to be part of its zone of influence, it managed to get its special interests recognized by these states including Sikkim (Bhutia, 2017). During 1950s, as China went on to explicitly express intentions to liberate Tibet (Bhutia, 2017), there were varying responses from India (being a regional hegemon) and small states such as Sikkim. For instance, Indian leadership perceived this intention and move by China to liberate Tibet as an attempt to end the buffer between India and China. As a result, it quickly moved on to conclude the Indo-Sikkim treaty whereby Sikkim was declared an Indian protectorate in 1950 (Bhutia, 2017). India did not openly occupy Sikkim at that stage, because it might have thought that this action could provoke China and also make Nepal and Bhutan wary of India's intentions resulting in their likely shift towards China.

As China decisively defeated India in 1962, Sikkim's rulers considered that India was no more a hegemon or in a position to secure it (Bhutia, 2017). Accordingly, Sikkim started getting closer to China. The war events of 1962 and clashes between India and China in 1967 would probably have led to the self-perception of being strategically important to Sikkim. Accordingly, as Sikkim gave positive overtures to China, the latter also immediately reciprocated with a view to enhancing its own sphere of influence in the region (Lidarev, 2015) (an approach common to counter-hegemons as discussed earlier). This led India to trigger internal political turmoil for Sikkim's rulers through support of political forces already set against the King of Sikkim, because, in Indian perception the King had failed to secure special interests of India and his overtures towards China were hostile in character for India. A political opponent of Sikkim's king namely Kazi Lhendup Dorji was accordingly launched to the forefront (Gupta, 1975). The political unrest across Sikkim that ensued led to India's ultimate occupation of Sikkim (Bhutia, 2017).

\subsection{SRI LANKA}

It is estimated that during the past 2500 years, India has invaded Sri Lankan territory 17 times (Silva, 2013). This had led to Sri Lanka's peculiar perceptions regarding India as a hegemon with expansionist ambitions against the former's territory.

Sri Lanka's foreign policy has remained dominated by the factors of bandwagoning as well as balancing to deter Indian expansionism. Initially, following British withdrawal from the subcontinent, Sri Lanka bandwagoned the British (now an extra regional power) in order to counter Indian hegemony (Gunasekara, 2015). Later on, Sri Lanka also played an important role in the Non-Aligned Movement (NAM) which served as a sort of alliance for Sri Lanka to curb and minimize the role of India and other greater powers in the Indian Ocean region (Gunasekara, 2015). 
At its end, Indian leadership perceives Sri Lanka to be part of mythical India's territorial part and therefore has repeatedly suggested merger of India and Sri Lanka (Soysa, 2010) in the past. Accordingly, any attempt by Sri Lanka to assert its sovereignty even by inviting an extra regional power has historically caused serious concerns within the Indian political and military leadership. Accordingly, India started interfering in Sri Lanka's Tamil issue from early on, because it held the perception that if did not do so, the external players may use the Island as a "pressure point" against India and pose threat to its national security (Khobragade, 2008).

In a similar manner, when Sri Lanka, attempted to get closer to China especially during the Presidency of Rajapaksa, India started actively interfering in Sri Lankan politics and again started supporting Tamils against Rajapaksa, ultimately managing to topple his Government in 2015, through involvement in Sri Lankan elections (Brewster, 2015). These instances indicate that Sri Lanka's seemingly proactive approach towards the extra-regional powers including China, even though for asserting its own sovereignty, were always taken to be hostile acts by India as it perceived these actions to be amounting to risk-taking in character and essentially hostile towards India owing to their implied opposition to India's regional hegemony. Accordingly, not only that Sri Lanka had to face internal turmoil but also that the regional players got more intensely entangled in that country leading to their hefty economic commitments.

\subsection{MALDIVES}

Maldives is another country in South Asia that considers itself a 'small state'. A major parameter to gauge this element is that Maldives has been consistently propagating the cause of ensuring security of small states through international support at different multilateral for a (Khaleel, 1999). This hints that Maldives considers that it does not have the capability to secure its sovereignty on its own.

In view of India's increasing involvement in Maldivian politics, Maldives former President Abdullah Yameen had attempted to reassert his country independence after taking over power in 2013. However, this act by Maldives was taken as an affront by India. As the former Maldives President attempted to court China and managed to attract Chinese contracts worth around US\$ 2-3 billion (Sibal, 2020), India perceived this move to be direct threat to its 'sphere of influence' that included Maldives and therefore allegedly worked behind the scenes to ensure Abdulla Yameen's removal from office (Eurasian Times Desk, 2018). Subsequently, India announced up to US\$ 4 billion worth of financial assistance to Maldives (Mallempati, 2019). However, it now appears that as Maldives has drifted towards the hegemon, this may lead to increase in economic difficulties for the small island country as it would need to examine as to whether India would allow its financial assistance to be used to repay Chinese loans.

\subsection{BANGLADESH}

Bangladesh can also be considered a small state on the basis of perceptions of its founding leadership, reflected through the country's limited foreign policy profile. For instance, Bangladesh's founder Sheikh Mujib-ur-Rahman identified his country to be a small state (Huzen, 2019).

Bangladesh's has historically been bandwagoning India ever since its creation in 1971. However, recently, the passage of controversial Citizenship Amendment Act (CAA) in India has caused much consternation in Bangladesh as it is considered to be unnecessary and a possible causal 
factor for demographic tensions between the Muslim and Hindu religious communities. Bangladesh is also concerned about the return of millions of Bangladeshi citizens currently living in India, back into the country (Islam, 2020). As a result, Bangladesh appears to be repositioning its regional priorities. China has already started undertaking major infrastructure projects in Bangladesh including establishing a major smart city near Dhaka and an airport in Sylhet coupled with defence relationship (BASU, 2020). In addition, China has allowed 97 percent of Bangladeshi export items to enter its territory duty and quota free (BASU, 2020). An interesting phenomenon can be observed as to how India, in its response, is now attempting to counter China's increasing influence in Bangladesh through inclusion of extra-regional powers in the region. The QUAD (US, India, Japan and Australia) has now been engaging Bangladesh on more proactive basis. The US has for instance been hinting at a "reset" of its relations with Bangladesh recently (Chowdhory, 2020). While the final outcome of these developments is yet to be seen, it is evident that as part of its strategy to keep the regional countries under its influence, a hegemon can even attempt to include extra-regional powers in the region.

\subsection{BHUTAN}

Bhutan is another country in South Asia which in addition to the different quantitative elements perceives itself a small state. This element is signified by the fact that Bhutan perceives itself to be unable to run its own foreign policy and is therefore bound to be guided by India in this regard under Article 02 of the Treaty of Friendship and Cooperation 1949 (Mahajan, 2018).

While being entirely dependent on India under the so-called Friendship Treaty of 1949 (Ahmad, 2020), Bhutan has been getting dissatisfied with India's handling of its external policy (Ahmad, 2020) for quite some time. Bhutan also perceives that its problems with China are essentially because of its very close relations with India (Ahmad, 2020). Accordingly, Bhutan has been attempting to draw a sort of balance in terms of its relations with China and India in recent years (Ahmad, 2020) as part of its gaming approach. Bhutan's debt problems with India and increasing unemployment have led to its increasing orientation and attraction towards China as well (Bubna, 2020). The case study of Bhutan depicts as to how in certain instances, a small state even while clearly siding with a hegemon may find itself insecure and get caught in a dilemmatic situation when it ponders over a balancing act between hegemon and a counter-hegemon. It is an especially difficult circumstance for such a small state because, the hegemon may treat such attempts by the small state as an affront and take punitive actions against such a small state, resulting in further compromise on the latter's sovereignty. Bhutan's case also manifests as to how a hegemon can perceive a posturing of neutrality by its erstwhile ally in respect of a counterhegemon as an affront and a risk-taking behavior on the part of a small state. As an example, in 2012, when Bhutan's Prime Minister Jigme Thinly met Chinese Premier Wen Jiabo on the margins of Rio+20 Summit, India strongly reacted to this development and withdrew all fuel subsidies for Bhutan (Kumar, 2019). This manifests as to how India perceived Bhutan's overtures towards China as risk-taking actions and responded through strict actions against this small state. 


\section{CONCLUSION}

The above paper while employing a constructivist theoretical framework for the game theory approach attempts to redefine the players in a system as small states, hegemonic as well as counter-hegemonic states and concludes that these conceptualizations are essentially based on the perceptions, beliefs, role conceptualizations and ideals of the players regarding their "self" and "others". The above paper then moves on to identify the dilemma faced by small states in a system and highlights that even if a small state attempts to balance its relations between a hegemon and counter-hegemon; bandwagon either of the great powers in the system; or hedge vis-à-vis the hegemon or counter-hegemon, its actions would always be interpreted differently by either of the greater powers resulting in perennial threat to small state's sovereignty. The paper then introduces the concept of strategic risk-taking to identify that any action by the small state aimed at securing its sovereignty or with a peculiar role conceptualization of serving as a necessary weight in the system for deciding regional leadership of a hegemon or a counterhegemon always turns out to be counter-productive, as the hegemon or counter-hegemon assume these actions to be risk-taking in character and resultantly hostile to their interests. Resultantly, these actions (or inactions) by the small state, even if they may sound docile, would be taken as risk-taking by the small state and result in punitive measures, mostly by the hegemon, against the small state in addition to creation of security dilemmatic situation between the hegemon and counter-hegemon leading up to volatilities in escalation ladder. The paper presents the case study of different small states of South Asia to elaborate that whenever, a small state in South Asia has attempted to balance its relations between the regional hegemon (India) and counter-hegemon (China), it has always been perceived as a risk-taking action by India and resulting in punitive measures against the small states of the region.

\section{REFERENCES}

Adhikari, D. R. (2018, July). A SMALL STATE BETWEEN TWO MAJOR POWERS: NEPAL'S FOREIGN POLICY SINCE 1816. Journal of International Affairs, 02(01), 4374.

Ahmad, M. (2020, August 17). India revamping its Relation with Bhutan amidst the India- China Border Conflict. Retrieved December 13, 2020, from https://moderndiplomacy.eu/2020/08/17/india-revamping-its-relation-with-bhutan-amidstthe-india-china-border-conflict/

Associated Press. (2019, October 12). Xi Becomes 1st Chinese President in 2 Decades to Visit Nepal. Retrieved December 14, 2020, from https://www.voanews.com/east-asia-pacific/xibecomes-1st-chinese-president-2-decades-visit-nepal

BASU, N. (2020, July 31). China takes Bangladesh into its embrace now as Delhi-Dhaka ties go downhill. Retrieved December 13, 2020, from https://theprint.in/diplomacy/china-takesbangladesh-into-its-embrace-now-as-delhi-dhaka-ties-go-downhill/471769/

BASU, N. (2020, May 27). Madhesis back at centre of Delhi-Kathmandu row as they 'block bill to change Nepal map'. Retrieved December 28, 2020, from 
https://theprint.in/diplomacy/madhesis-back-at-centre-of-delhi-kathmandu-row-as-theyblock-bill-to-change-nepal-map/430499/

Bhutia, S. D. (2017, June). INDIA'S FOREIGN POLICY: PRIOR SIKKIM'S MERGER. IOSR Journal Of Humanities And Social Science, 22(6), 93-98.

Bjøl, E. (1971). The Small State in International Politics. In A. Schou, \& A. O. Brundtland (Eds.), Small States in International Relations (pp. 29-39). Stockholm: Almqvist and Wiksell.

Brewster, D. (2015, September 17). Sri Lanka tilts back from China. Retrieved December 13, 2020, from https://www.eastasiaforum.org/2015/09/17/sri-lankas-tilts-back-from-china/

Bubna, V. (2020, September 13). Is Bhutan slowly turning tides against India because of IndiaChina tensions? Retrieved December 13, 2020, from https://moderndiplomacy.eu/2020/09/13/is-bhutan-slowly-turning-tides-against-indiabecause-of-india-china-tensions/

Chowdhory, M. R. (2020, October 20). Quad diplomacy: Where does Bangladesh stand? Retrieved December 13, 2020, from https://southasianmonitor.net/en/top-news/quaddiplomacy-where-does-bangladesh-stand

Destradi, S. (2010). India and the Civil War in Sri Lanka: On the Failures of Regional Conflict Management in South Asia. hamburg: German Institute of Global and Area Studies.

Efremova, K. (2019). Small States in Great PowerPolitics: Understanding the "Buffer Effect". Central European Journal of International and Security Studies, 13(I), 100-121.

Eurasian Times Desk. (2018, September 28). Did India Work 'Behind The Scene' To Topple Yameen Government in Maldives? Retrieved December 13, 2020, from https:/eurasiantimes.com/india-topple-abdulla-yameen-government-in-maldives/

Feer, M. (1953). India's Himalayan Frontier. Far Eastern Survey, 22(11), 137-141.

Finnemore, M., \& Sikkink, K. (2001). Taking stock: The constructivist research program in international relations and comparative politics. Annual Review of Political Science, 391416.

FP Staff. (2020, December 25). As political crisis in Nepal deepens, India-China tug of war over Hindu nation set to intensify. Retrieved December 25, 2020, from https://www.firstpost.com/india/as-political-crisis-in-nepal-deepens-india-china-tug-of-warover-hindu-nation-set-to-intensify-9141151.html

Goodby, J. (2014). The Survival Strategies of Small Nations. Survival, 56(05), 31-39.

Gunasekara, S. N. (2015). Bandwagoning, Balancing, and Small States: A Case of Sri Lanka. Asian Social Science, 11(28).

Gunasekara, S. N. (2015, November 27). Bandwagoning, Balancing, and Small States: A Case of Sri Lanka . Asian Social Science, 11(28), 212-220.

Gupta, R. (1975, September). Sikkim: The merger with India. Asian Survey, 15(9), 786-798. 
Haidar, S., \& Bhattacherjee, K. (2016, September 06). Nepal seals agreement on transit rights through China. Retrieved December 14, 2020, from https://www.thehindu.com/news/international/nepal-inks-transit-treaty-with-china-to-havefirst-rail-link/article8381195.ece

Heng, Y., \& Aljunied, A. (2015). Can Small States Be More than Price Takers in Global Governance? Global Governance, 21(03), 435-454.

HIMALAYAN NEWS SERVICE. (2020, July 13). Rift between Nepal's ruling party chairpersons widening? Retrieved December 15, 2020, from https://thehimalayantimes.com/nepal/rift-between-nepals-ruling-party-chairpersonswidening/

Hopf, T. (2002). Social Construction of International Politics: Identities and Foreign Policies, Moscow, 1955 and 1999. Ithaca: Cornell University Press.

Hughes, A. W. (2007). Game Theory as a Decision Making Tool for Leaders:An Evaluation Using Huntington's Clash of Civilization Model . Virginia: Regent University.

Huzen, D. K. (2019, September). FOREIGN POLICY OF BANGLADESH: THE DILEMMAS OF WEAK STATE. Retrieved December 03, 2020, from https://www.researchgate.net/publication/335975448_FOREIGN_POLICY_OF_BANGLA DESH_THE_DILEMMAS_OF_WEAK_STATE/citations

IANS. (2020, September 02). Nepal directs its forces to "closely monitor" Indian Army activities at Lipulekh. Retrieved December 25, 2020, from https://economictimes.indiatimes.com/news/defence/nepal-directs-its-forces-to-closelymonitor-indian-army-activities-at-lipulekh/articleshow/77887865.cms

Ilgit, A., \& Ozkececi-Taner, B. (2012). Identity and Decision Making: Toward a Collaborative Approach to State Action. In V. P. Shannon, \& P. A. Kowert (Eds.), Psychology and Constructivism in International Relations: An Ideational Alliance. University of Michigan.

India Today Web Desk. (2020, May 20). Nepal launches new map including Lipulekh, Kalapani amid border dispute with India. Retrieved December 14, 2020, from https://www.indiatoday.in/india/story/nepal-new-map-includes-lipulekh-kalapani-amidborder-dispute-1680041-2020-05-20

Islam, A. (2020, July 30). Can China and Pakistan profit as Bangladesh turns from India? Retrieved December 13, 2020, from https://www.dw.com/en/can-china-and-pakistan-profitas-bangladesh-turns-from-india/a-54381028

Jung, H. (2019). The Evolution of Social Constructivism in Political Science: Past to Present. SAGE Open, 1-10.

Kantha, P. K. (2010). Understanding Nepal's Madhesi movement and its future trajectory. Himalayan Journal of Development and Democracy, 5(1), 31-40.

Kapor, P. (2016). GAME THEORY APPROACH TO CONFLICT AND COOPERATION IN INTERNATIONAL RELATIONS. 14th International Scientific Conference on Economic and Social Development, (pp. 242-250). Belgrade. 
Khaleel, A. (1999). OREIGN POLICY ORIENTATION OF SMALL ISLANDATES: AN EVALUATION OF THE FOREIGN POLICIES OF NUATU AND THE MALDIVES. PhD Thesis, University of Canterbury.

Khobragade, V. F. (2008, Oct-Dec). INDIAN APPROACH TOWARDS SRI LANKAN CONFLICTS. The Indian Journal of Political Science, 69(04), 911-917.

Kockesen, L., \& Ok, E. A. (2007). An Introduction to Game Theory. Istanbul: Koc University.

Kumar, K. (2019, July 05). Is India Losing Its Grip on Bhutan? Retrieved December 28, 2020 , from https://thediplomat.com/2019/07/is-india-losing-its-grip-on-bhutan/

Larson, D. W. (2012). How Identities Form and Change:Supplementing Constructivism with Social Psychology. In V. P. Shannon, \& P. A. Kowert (Eds.), Psychology and Constructivism in International Relations: An Ideational Alliance (p. 58). University of Michigan.

Levy, J. S. (1992, June). Prospect Theory and International Relations: Theoretical Applications and Analytical Problems. Political Psychology, 13(2), 283-310.

Lidarev, I. (2015, December 31). The Sikkim Anniversary. Retrieved December 13, 2020, from https://thediplomat.com/2015/12/the-sikkim-anniversary/

Mahajan, S. (2018, March 06). India-Bhutan Relations: Past, Present and Future. Retrieved December 03, 2020, from http://www.southasiaathudson.org/blog/2018/3/6/india-bhutanrelations-past-present-and-future

Mallempati, S. (2019, April 12). India-Maldives relations improving despite obstacles. Retrieved December 13, 2020, from https://www.eastasiaforum.org/2019/04/12/india-maldivesrelations-improving-despite-obstacles/

Malone, T. D. (2012). Historical Influences on India's Foreign Policy. International Journal, 1029-1049.

Mauldin, W., \& Shah, S. (2020, October 28). Pompeo Visits Sri Lanka as It Deepens China Relationship. Retrieved December 13, 2020, from https://www.wsj.com/articles/pompeovisits-sri-lanka-as-it-deepens-china-relationship-11603888037

McDermott, R. (1998). Risk-Taking in International Politics: Prospect Theory in American Foreign Policy. Michigan: The University of Michigan Press.

Mohammadzadeh, B. (2017). Status and Foreign Policy Change in Small States: Qatar's Emergence in Perspective. THE INTERNATIONAL SPECTATOR, 52(02), 19-36.

Moorthy, N. S. (2020, October 26). As Sri Lanka moves closer to China, what does this mean for India and its interests? Retrieved December 13, 2020, from https://www.firstpost.com/india/as-sri-lanka-moves-closer-to-china-what-does-this-meanfor-india-and-its-interests-8951771.html

Mushelenga, P. (2014). Principles and principals of Namibia's foreign relations. In A. Bösl, A. d. Pisani, \& D. U. Zaire (Eds.), Namibia's Foreign Relations: Historic contexts, current dimensions and perspectives for the 21 st Century (pp. 59-78). Windhoek: Konrad Adenauer Foundation. Retrieved from Konrad Adenaeur Stiftung. 
Mushelenga, P. (2015). THE ECONOMIC DIPLOMACY OF A SMALL STATE: THE CASE OF NAMIBIA. Pretoria: University of South Africa.

Myerson, R. B. (1991). Game Theory: Analysis of Conflict. London: Harvard University Press.

Neumann, J. V., \& Morgenstern, O. (1944). Theory of games and economic behavior. Princeton, NJ: Princeton University Press.

O’Neill, B. (2001, August). Risk Aversion in INternational Relations Theory. International Studies Quarterly, 45(4), 617-640.

Press Trust of India. (2020, November 30). Defence minister of China visits Nepal to bolster military ties. Retrieved December 15, 2020, from https://www.businessstandard.com/article/international/defence-minister-of-china-visits-nepal-to-bolstermilitary-ties-120112900759_1.html

Press Trust of India. (2020, November 04). Indian Army Chief General MM Naravane arrives in Kathmandu. Retrieved December 04, 2020, from https://economictimes.indiatimes.com/news/defence/indian-army-chief-general-mmnaravane-arrives-in-kathmandu/articleshow/79038054.cms

Press Trust of India. (2020, November 26). Indian foreign secretary arrives in Nepal on 2-day trip. $\quad$ Retrieved December 20, 2020, from https://www.theweek.in/news/india/2020/11/26/indian-foreign-secretary-arrives-in-nepalon-2-day-trip0.html

Rasmusen, E. (2004). GAMES AND INFORMATION: An introduction to the Game Theory (Third ed.). Blackwell Publishing.

Rose, L. (1971). Nepal: Strategy For Survival. Berkeley: University of California Press.

Rose, L. E. (1969). India and Sikkim: Redefining the relationship. Pacific Affairs, 42(1), 32-46.

Saleem, B. G. (2013). CHINA'S POLICY TOWARDS SOUTH ASIA- AN APPRAISAL. Defence Forum .

Salman, M., \& Geeraerts, G. (2015). Strategic Hedging and Balancing Model under the Unipolarity. Midwest Political Science Association. Chicago.

Sibal, S. (2020, November 18). India backs Maldives to hilt as China's debt leaves negative legacy. Retrieved December 13, 2020, from https://www.dnaindia.com/india/report-indiabacks-maldives-to-hilt-as-china-s-debt-leaves-negative-legacy-2857166

Silva, A. I. (2013). International Intervention in Intra State conflicts: The Case in Sri Lanka. California: naval Postgraduate School, Monterey, California.

Soysa, D. (2010, November 06). The Island Online. Retrieved March 17, 2020, from http://www.island.lk/index.php?page_cat=article-details\&page=articledetails\&code_title $=10696$

Steinsson, S., \& Thorhallsson, B. (2017). Small State Foreign Policy. In The Oxford Research Encyclopedia of Politics. Oxford University Press.

Suhrwardy, Z. (1996, January). India's Relations with Nepal. Pakistan Horizon, 49(01), 35-54. 


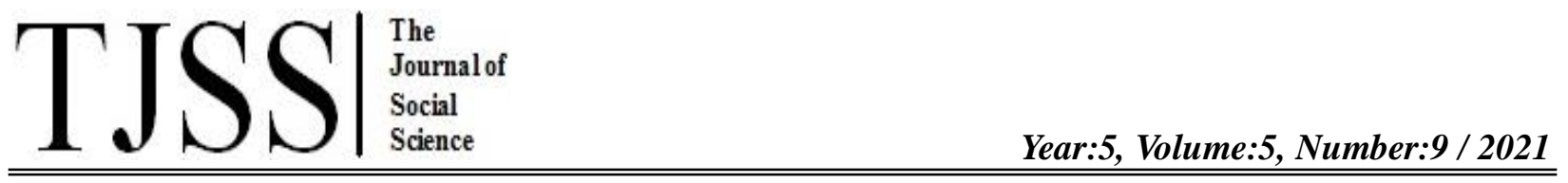

Tahir-Kheli, S. (1978). Chinese Objectives in South Asia: "Anti-Hegemony" vs. "Collective Security". Asian Survey, 18(10), 996-1012.

Tema, M. (2014). Basic Assumption in Game Theory and International Relations. International Relations Quarterly, 05(01).

Tessman, B. (2012). System Structure and State Strategy: Adding Hedging to the Menu. Security Studies, 21(02), 193.

Tessman, F. B., \& Wolfe, W. (2011). Great Powers and Strategic Hedging: The Case of Chinese Energy Security Strategy. International Studies Review, 13(02), 214-240.

Upadhya, S. (2012). Nepal and the Geo-Strategic Rivalry between China and India. London; New York: Routledge.

Vandenbosch, A. (1964). The Small States in International Politics and Organization. The Journal of Politics, 26(02), 293-312.

Vis, B. (2018, July). Prospect theory and foreign policy decision-making: Underexposed issues, advancements, and ways forward. Contemporary Security Policy, 39(2), 1-15.

Wendt, A. (1999). Social Theory of International Relations. New York: Cambridge University Press.

Whelpton, J. (2005). A History of Nepal. Delhi: Cambridge University Press.

Wojczewski, T. A. (2016). India and the Quest for World Order:Hegemony and Identity in India's Post-Cold WarForeign Policy Discourse. Christian-Albrechts-Universität.

Womack, B. (2016). Asymmetry and International Relationships. Cambridge: Cambridge University Press. 